\title{
Research of the Factors Responsible for Gender Violence in Home and School Environment
}

\author{
Dayal Pyari, Alka Muddgal
}

\begin{abstract}
Violence is a global issue that has received considerable attention during recent years. Available research has suggested various factors, mostly family and social factors, to possibly affect violence. As previous studies have not examined the relationship between these factors and violent behaviors in adolescents, this research was aimed to assess the relationship between environmental factors and violence in adolescents. The collected data was analyzed by applying multiple regression analysis. Most participants lived in urban areas and about half of them were females. Linear regression test showed violent behaviors to have significant, inverse relationships with love and affection in the family and watching drama and comedy movies. Significant, direct relationships were found between violent behaviors in adolescents and aggressive behaviors in the family and watching crime, police, and action movies. However, the incidence of violent behaviors was not significantly related with the effects of peers and presence of sports facilities.

The findings supported that love and affection and healthy pastime (e.g. watching comedy and drama movies) in the family reduce violent behaviors in adolescents. In contrast aggressive behaviors in the family, watching crime, police, and action movies were found to increase violent behaviors in adolescents.
\end{abstract}

KEYWORDS: Gender violence, Home Environment and School Environment

\section{INTRODUCTION}

Gender violence is the violence directed against a person on the basis of gender. It constitutes a breach of the fundamental right to life, liberty, security and dignity, equality between girls and boys, non- discrimination and physical and mental integrity. Gender violence is described by many as the most prevalent human rights violation in the world. Of the varied ways in which sex discrimination manifests itself across the globe, such violence is exceptionally dehumanizing, pervasive and oppressive. Gender-based violence both reflects and reinforces inequalities between girls and boys. At least one in three girls around the world is estimated to have been coerced into sex, physically beaten and/or otherwise abused in her lifetime. It is a global phenomenon that knows no geographical, cultural, social, economic, ethnic, or other boundaries which occurs across all societies and represents a brutal violation of human rights, the worst manifestation of gender-based discrimination and a major obstacle to the achievement of gender equality. It is tolerated and sustained by social institutions, including the school, the very place where we expect our children to be safe and protected. It is a serious obstacle to the right to education and learning, with

Revised Manuscript Received on October 22, 2019.

Dr. Dayal pyari, assistant professor, aie, (amity university, noida, up), e.mail: dpyari@amity.edu

Prof. (dr.) Alka muddgal, head of the institute, aie, (amity university, noida, up), e.mail: amuddgal@amity.edu.

implications for the ways that people understand and enact their social lives and exercise their citizenship.

The United Nations Declaration (1991) on the Elimination of Violence against Women was the first international human rights instrument to deal exclusively with gender-based violence. It defines gender violence as: "any act that results in, or is likely to result in, physical, sexual or psychological harm or suffering to women, including threats of such acts, coercion or arbitrary deprivations of liberty, whether occurring in public or private life."

The World Health Organization defines violence as "the intentional use of physical force or power, threatened or actual, against oneself, another person, or against a group or community, which either results in or has a high likelihood of resulting in injury, death, psychological harm, deprivation". International consensus statement, the Platform of Action from the 1995 Fourth World Conference on Women (Beijing), explains that Gender violence includes physical, sexual and psychological violence in the family or within the general community, including battering; sexual abuse of female children; dowry-related violence; marital and non-marital rape; traditional practices harmful to women; sexual harassment and intimidation at work, in educational institutions and elsewhere. The achievement of Education for All (EFA) goals and Millennium Development Goals (MDGs) is seriously compromised by violence in the educational environment. Evidence shows that many schools in the region, both private and public, are not safe with protective environments for children. Causal links between school violence and drop-out rates are being established in many countries in the region, and sexual violence is increasingly understood as a particularly pressing problem, especially for girls. Coming up with one sole definition of violence is very difficult. This aspect of human behavior has been studied from many different approaches, and each of them focuses on a specific part. Therefore one would find many definitions of violent behavior that reflect the heterogeneity of the theories underneath. It is necessary to add that the term violence is used on many occasions as a synonym for aggression even in prestigious publications. Even though aggression and violence might seem equivalent there is a general agreement in the difference of their nature or origin. Further, social learning theory contends that children who observe and experience violence within the family are likely to accept aggression as a legitimate way to interact with others. 


\section{Research of the Factors Responsible for Gender Violence in Home and School Environment}

When aggressive behavior is demonstrated at home, it may be more likely that bullying will be played out in other interactions and settings, such as among peers and in schools. Family violence can also be linked to school participation. There is some evidence that young girls are particularly vulnerable to sexual violence within the home environment, perpetrated by male caregivers.

\section{STATEMENT OF THE PROBLEM}

The present problem undertaken by the investigator can be stated as "Research of the factors responsible for the gender violence in home and in school of secondary school students in New Delhi Region".

\section{OBJECTIVES OF THE RESEARCH}

1. To identify the forms of gender violence among student in school and home environment.

2. To determine the causes of gender violence amon students in school and home environment.

3. To evaluate the effect of gender violence among students in school and home environment.

\section{RESEARCH QUESTIONS}

The research questions are as follows:

1. What are the reasons for the gender violence?

2. What are the most common prevailing factors for gender violence? gender violence?

\section{V.RESEARCH METHODOLOGY}

In the present research the variables were classified as under:

\section{DEPENDENT VARIABLES:}

The dependent variables are Gender Violence in home environment and in school environment.

\section{INDEPENDENT VARIABLES:}

In the present research the following variables are considered as independent variables and broadly categorized under three headings which are presented as under.

Independent variables, which were considered in the presented research are individual, family, social and school factors.

\section{METHOD OF THE RESEARCH}

In this Ex-Post-Facto method of research was used. The psycho-socio-biographical variables have already occurred and only their dependent variables remain under research observation i.e. the independent variables (Psychological, social and biographical) have been studied in retrospect for their possible relation to and effects on the dependent variable since none of these independent variables are subject to direct
3. What action can be taken to reduce or minimize

manipulation and are manipulated through selection only, hence Ex-Post-Facto method of research has been followed.

\section{SELECTION OF THE SAMPLE}

To select the institutions from which target sample have been taken, first the investigator brought the list of Intermediate colleges of New Delhi Region with Government and private colleges.

After having the list of intermediate colleges of New Delhi region, the institutions were considered Keeping in view of the representativeness of the Sample. All the institutions were classified according to their affiliation as under Government and Private from each category four institutions were selected by simple random method. The final sample 400 students were selected from the total cluster of the students of $9^{\text {th }}$ class sof each institution by using simple random sampling for the selection of the class sections and total number of students in ghese sections were included in sample selection of selected cluster.

\section{TOOLS}

Research instruments should be selected in accordance with the objectives of the research, information required and applicability to the specific age group of the subjects to be studied. The following tools have been used for collection of data:

1. Self-constructed Test to identify the students affected by gender violence.

2. Test for school environment by Dr. K.S. Misra.

3. Test for home environment by Dr. K.S. Misra.

\section{X.STATISTICAL TECHNIQUES}

The researcher adopted various measures of statistics in order to arrange and thrash out the essence from the collected data and to make the data meaningful. The following statistical techniques have been used:

1. Descriptive Statistics: Mean, Standard deviation, Zero order Correlation, Coefficient of Correlation.

2. Inferential Statistics: Coefficient of Multiple Correlations, Regression Analysis.

\section{INTERPRETAION OF DATA}

\section{REGRESSION COEFFICIENT OF GIRLS AND BOYS}

In order to subject the level of Regression Coefficient of gender violence scores of Girls and Boys groups were calculated. 
Table no.1: Regression coefficients for boys and girls

Table no.l: Regression coefficients for boys and girls

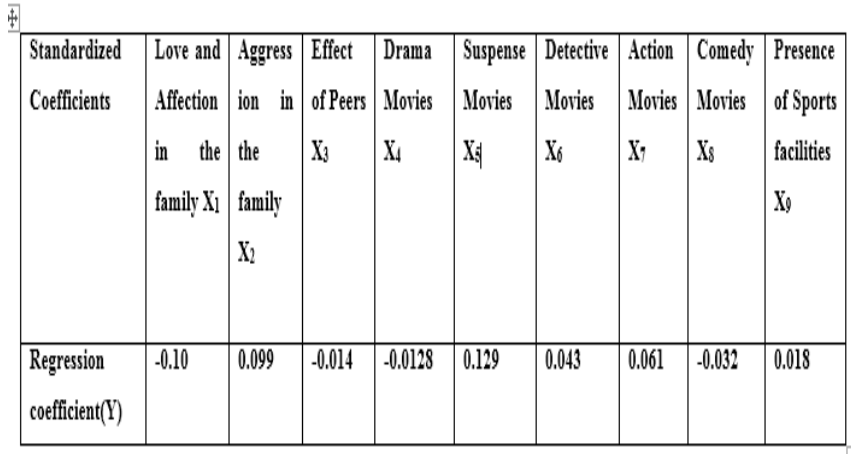

$Y=-0.10 X_{1}+0.099 X_{2}-0.014 X_{3}-0.0128 X_{4}+0.129 X_{i}+0.043 X_{6}+0.061 X_{7}-0.032 X_{8}+0.018 X_{9}$

Among the 400 randomly selected students, $89.1 \%$ were urban, and $10.9 \%$ were rural. Junior high and high school students constituted $45.3 \%$ and $53.7 \%$ of the participants, respectively. Multiple regression was applied to examine the relationships between environmental factors (predictors or independent variables) and adolescents' violent behaviors (dependent variable or criterion). The environmental factors included the presence or absence of sports facilities, type of movies watched by adolescents (drama, suspense, detective, action, and comedy movies), the importance of the subjects put on their peers, and family relationships (level of love and affection among family members and aggressive behaviors between parents)

As observed in Table no. 1, the incidence of violent behaviors had significant, inverse relationships with love and affection in the family and watching drama and comedy movies. Meanwhile, it was significantly and directly related to aggressive behaviors in the family (especially between parents) and watching crime, police, and action movies. However, the incidence of violent behaviors was not significantly related to the effects of peers and presence or absence of sports facilities in the neighborhood.

\section{REGRESSION COEFFICIENT FOR GIRLS AND BOYS}

In order to subject the level of Regression Coefficient of gender violence, scores for Groups of Girls and Boys were calculated.

Table no.2: Regression coefficients for boys and girls

\begin{tabular}{|l|l|l|}
\hline Variables & \multicolumn{2}{|l|}{ Statistical Parameters } \\
\hline & Girls & Boys \\
\hline & $\begin{array}{l}\text { Regression } \\
\text { coefficient } \mathbf{Y}_{\text {Girls }}\end{array}$ & $\begin{array}{l}\text { Regression } \\
\text { coefficient } \mathbf{Y}_{\text {Boys }}\end{array}$ \\
\hline Love and Affection & -0.113 & -0.106 \\
\hline
\end{tabular}

\begin{tabular}{|l|l|l|}
\hline in the family $\mathrm{X}_{1}$ & & \\
\hline $\begin{array}{l}\text { Aggression in the } \\
\text { family } \mathrm{X}_{2}\end{array}$ & 0.157 & 0.118 \\
\hline Effect of Peers $\mathrm{X}_{3}$ & -0.004 & 0.018 \\
\hline Drama Movies $\mathrm{X}_{4}$ & -0.049 & -0.034 \\
\hline $\begin{array}{l}\text { Suspense Movies } \\
\mathrm{X}_{5}\end{array}$ & 0.082 & 0.157 \\
\hline $\begin{array}{l}\text { Detective Movies } \\
\mathrm{X}_{6}\end{array}$ & 0.002 & 0.002 \\
\hline $\begin{array}{l}\text { Action Movies } \mathrm{X}_{7} \\
\text { Comedy Movies } \mathrm{X}_{8}\end{array}$ & -0.253 & -0.016 \\
\hline facilities $\mathrm{X}_{9}$ & -0.013 & -0.052 \\
\hline
\end{tabular}

$\mathrm{Y}$ Girls $=-0.113 \mathrm{X} 1+0.157 \mathrm{X} 2-0.004 \mathrm{X} 3-0.049 \mathrm{X} 4+0.082$ $\mathrm{X} 5+0.002 \mathrm{X} 6+0.016 \mathrm{X} 7-0.253 \mathrm{X} 8-0.013 \mathrm{X} 9$

Y Boys $=-0.106 \mathrm{X} 1+0.118 \mathrm{X} 2+0.018 \mathrm{X} 3-0.034 \mathrm{X} 4+0.157$ X5 +0.002 X6 -0.018 X7 -0.052X8 -0.006 X9

According to table no 2 violent behaviors in girls had a significant direct relationship with watching suspense movies and significant, inverse relationships with love and affection in the family and aggressive behaviors in the family (especially between parents). Suspense movies and other independent variables had no significant influence on violent behaviors in adolescent girls.

Violent behaviors in boys were significantly and inversely related to love and affection in the family and watching comedy movies. On the other hand, it had significant and direct relationships with aggressive behaviors in the family (especially between parents) and watching suspense movies. No other significant relations found detected between violent behaviors in boys and detective movies the rest of independent variables.

\section{REGRESSION COEFFICIENT OF GIRLS AND BOYS OF URBAN AND RURAL STUDENTS}

In order to subject the level of Regression Coefficient of gender violence scores of Girls and Boys in rural and urban groups were calculated. 
Research of the Factors Responsible for Gender Violence in Home and School Environment

Tables no. 3: Regression coefficients for urban and rural students

\begin{tabular}{|c|c|c|}
\hline Variables & \multicolumn{2}{|c|}{ Statistical Parameters } \\
\hline & Girls & Boys \\
\hline $\begin{array}{c}\text { Regression } \\
\text { coefficient } \mathrm{Y}_{\text {Girls }}\end{array}$ & $\begin{array}{c}\text { Regression } \\
\text { coefficient } \mathrm{Y}_{\text {Boys }}\end{array}$ \\
\hline $\begin{array}{c}\text { Love and Affection } \\
\text { in the family } \mathrm{X}_{1}\end{array}$ & -0.103 & -0.057 \\
\hline $\begin{array}{c}\text { Aggression in the } \\
\text { family } \mathrm{X}_{2}\end{array}$ & 0.095 & 0.123 \\
\hline $\begin{array}{c}\text { Effect of Peers } \mathrm{X}_{3} \\
\text { Drama Movies } \mathrm{X}_{4}\end{array}$ & -0.131 & -0.165 \\
\hline Suspense Movies $\mathrm{X}_{5}$ & 0.124 & 0.115 \\
\hline $\begin{array}{c}\text { Detective Movies } \\
\mathrm{X}_{6}\end{array}$ & 0.054 & 0.089 \\
\hline $\begin{array}{c}\text { Action Movies } \mathrm{X}_{7} \\
\text { facilities } \mathrm{X}_{9}\end{array}$ & -0.069 & 0.048 \\
\hline Comedy Movies $\mathrm{X}_{8}$ & -0.027 & -0.131 \\
\hline
\end{tabular}

$\mathrm{Y}$ Girls $=-0.103 \mathrm{X} 1+0.095 \mathrm{X} 2+0.000 \mathrm{X} 3-0.131 \mathrm{X} 4+0.124$ X5 -0.054 X6 -0.069 X7 -0.027 X8 +0.006 X9

Y Boys $=-0.057 \mathrm{X} 1+0.123 \mathrm{X} 2-0.119 \mathrm{X} 3-0.165 \mathrm{X} 4+0.115$ X5 +0.089 X6 +0.048 X7 -0.131 X8 -0.108 X9

Table no. 3 shows that among the urban students, the incidence of violent behaviors were significantly and inversely related to love and affection in the family and watching comedy movies. In contrast, significant, direct relationships existed between violent behaviors as the dependent variable and aggressive behaviors in the family (especially between parents) and watching crime, police, and action movies as independent families. Other relationships between dependent and independent variables were found to be not significant in urban adolescents.

Violent behaviors in rural students had significant, inverse relationships with having sports facilities, effects of peers, and watching drama and movies. There was also a significant and direct relationship between aggressive behaviors in the family (especially between parents) and the incidence of violent behaviors in rural adolescents. The rest of the independent variables had no significant relationships with violent behaviors in rural students.

\section{RESULT AND DISCUSSION}

Our findings highlighted significant, inverse relationships between violent behaviors among all students and love and affection in the family and watching drama comedy movies. Significant, direct relationships were also found between adolescents' violent behaviors and aggressive behaviors especially between parents and watching crime, police, and action movies. No significant relations were found between violent behaviors of adolescents and the effects of peers or the presence of sports facilities. Moreover, all were in agreement that media violence leads to violent behaviors, indifference to violence, heartlessness, having nightmares, and worrying about getting injured. Apparently, although the destructive effects of violent movies have been well determined, little attention has been paid to the positive effects of drama and comedy movies that can be good sources of information positive values and entertainment. Considering these two genres can be extremely beneficial in interventions aiming to prevent the aggressive behaviors of adolescents. Research has suggested a clear relationship between family life and delinquency. In fact, level of father-son discipline, the way the mother monitors his son's behavior, love and affection expressed by the parents to their children, and cohesion of the family have been proposed as predictors of delinquency. A subject on the relationships between parenting styles and aggressive behaviors in adolescents found democratic parenting as the best method to decrease aggression and its components. Similarly, the findings indicated love and affection in the family and aggressive behaviors in the family, especially between parents, to substantially affect the incidence of violent behaviors in adolescents. Differences in factors influencing violent behaviors in girls and boys were also found. For instance, although watching comedy movies significantly reduced violence in boys, it had no such effect among girls. Besides, while watching suspense movies increased the incidence of violent behaviors in both sexes, it was a stronger predictor in boys. On the other hand, family relationships were stronger predictors in girls. Likewise, a previous subject reported ineffective and troubled families to have more considerable impacts on delinquency among girls than among boys. The results of the current research underscored various differences between urban and rural students. In fact, violent behaviors of urban students had significant, inverse relationships with love and affection in the family watching comedy movies. Meanwhile, significant, direct relationships existed between the incidence of violent behaviors among urban adolescents on the one hand and aggressive behaviors in the family, especially between parents, and watching crime, police, and action movies on the other. In contrast, the influence of peers, the presence or absence of sports facilities, and watching comedy movies had no significant relationship with violent behaviors of urban participants. 
However, evaluating rural students revealed significant, inverse relationships between violence and having sports facilities, effects of peers, and watching drama and movies. There was also a significant and direct relationship between aggressive behaviors in the family, especially between parents, and the incidence of violent behaviors in rural adolescents. Then again, watching crime, police, action, and comedy movies and love and affection in the family had no significant effects on violent behaviors among rural subjects. No research was found specifically on aggressive behaviors of adolescents. The researchers concluded that people from deprived areas may consider their own socioeconomic conditions considerably different with those of other members of the society.

\section{CONCLUSION}

This research is focused on home and school violence in adolescence. In the last decade there has been a steady increase in research analyzing problems of violent behavior among children and adolescents at school, reflecting the growing seriousness of these problems in India. In this different definitions of the concepts of "Home violence" and "school violence" were analyzed in an attempt to understand the topic better. The following aspects regarding problems of violence and victimization at school were analyzed: incidence of school violence and bullying in these educational centers; where these acts occur more frequently; psychosocial characteristics of aggressors, pure victims, and aggressive victims; and psychosocial consequences derived from the involvement in violent acts and victimization situations at school. Results obtained regarding some psychological factors such as self-esteem and depressive symptomatology were analyzed. Causes of school and home violence are based on research results from previous studies. Some individual factors repeatedly linked to school violence have been for example, level of empathy, poor satisfaction with life, nonconformist social reputation, and attitude to social norms and institutional authority. Family variables analyzed include quality of family environment, parent-adolescent communication, family conflicts, parental support and family cohesion. School factors refer to quality of classroom environment, friendships with classmates, teacher-student relationship, and social acceptance or rejection by peers. Within the social factors there is an increasing concern about the effect of mass media, the Internet and video games on children and adolescent behavior. Findings regarding all these factors are presented and examined in the present research. The increasing concern of the scientific, educational, administrative and political groups is based in the need to analyze and understand the precedents and consequences of violent behavior during school ages. These concerns are based on the seriousness and frequency of certain behaviors that tarnish the student's integrity. The destructive and antisocial behaviors in the school demotivate students from their learning process and teachers from their functions of educator and transmitters of knowledge and values. The school must increase, as well, the resources to pay attention to the appropriate intervention measures with the implicated students. When action is taken to stop violence towards a particular child, decisions about how to respond should always take account of the best interests of the child involved.
This means trying to stop the violence or deal with its effects, but not doing anything that might make the situation worse for the child. Violence that takes place within the family is usually seen as something 'private', and outsiders don't want to make a fuss or intervene in other people's business. But the right of every child to respect, dignity and physical well-being doesn't stop at the door of the family home. Governments are still responsible for making sure that children are protected at home as well as outside. On the following pages you will read more about what the Violence has done so far, and what the ideas are for future action. These recommendations apply to all the places where violence against children takes place. There are also more ideas for what should be done to stop violence in the home and family; at school, in institutions, in the workplace and in the community.

\section{REFERENCES}

1. Astor, R., Pitner, R. O., Benbenishty, R., and Meyer, H. A. (2002) Public concern and focus on school violence. In L. A. Rapp-Paglicci, A. R. Roberts and J. S. Wodarski (Eds.), Handbook of Violence pp. 262-302). New York: John Wiley and Sons, Inc.

2. Baumrind, D. (1978). Parental disciplinary patterns and social competence in children. Youth and Society, 9, 239-276.

3. Baumrind, D. (1991). The influence of parenting style on adolescent competence and substance use. Journal of Early Adolescence, 11, 56-95.

4. Bierman, K. L., Smoot, D. L. and Aumiller, K. (1993). Characteristics of aggressive-rejected, aggressive (nonrejected), and rejected (nonaggressive) boys. Child Development, 64, 139-151.

5. Blankemeyer, M., Flannery, D. J., and Vazsonyi, A. T. (2002). The role of aggression and social competence in children's perceptions of the child-teacher relationship. Psychology in the Schools, 39, 293-304.

6. Brendgen, M., Vitaro, F., Turgeon, L., Poulin, F., and Wanner, B. (2004). Is there a dark side of positive illusions? Overestimation of social competence and subsequent adjustment in aggressive and non-aggressive children. Journal of Abnormal Child Psycholgy, 32, 609- 624

7. Cillessen, A., van Ijzendoom, H., van Lieshout, C., and Hartup, W. (1992). Heterogeneity among peer rejected boys: Subtypes stabilities. Child Development, 63, 893- 905.

8. Darling, N., and Steinberg, L. (1993). Parenting style as context: An integrative model. Psychological Bulletin, 113, 487-496.

9. Demaray, M. P., and Malecki, C. K. (2002). The relationship between perceived social support and maladjustment for students at risk. Psychology in the Schools, 39, 305-316.

10. Demaray, M. P., Malecki, C. K., Davidson, L., Hogdson, K., and Rebus, P. (2005). The relationship between social support and student adjustment: A longitudinal analysis. Psychology in the Schools, 42, 691-706.

11. Dishion, T. J., Patterson, G. R., and Griesler, P. C. (1994). Peer adaptations in the development of antisocial behavior: A confluence model. Im L.R. Huesmann (Ed.), Current perspectives on aggressive behavior (pp. 61-95).

12. Dykeman, C., Daehlin, W., Doyle, S., and Flamer, H. S. (1996) Psychological predictors of school-based violence: Implications for school counsellors. School Counsellor, 44, 35-47.

13. Eisenberg-Berg, N., and Mussen, P. Empathy and Moral Development in Adolescence. Developmental Psychology, 14, 185-186.

14. Estévez, E., Herrero, J., Martínez, B., and Musitu, G. (2006). Aggressive and non-aggressive rejected students: an analysis of their differences. Psychology in the Schools, 43, 387- 400.

15. Estévez, E., Herrero, J., and Musitu, G. (2005). The influence of violent behavior and victimization at school on psychological distress: the role of parents and teachers. Adolescence, 40, 183-196.

16. Estévez, E., Martínez, B. and Musitu, G. (2006). La autoestima en adolescentes agresores y víctimas en la escuela: La perspectiva multidimensional [Self-esteem in aggressors and victims of schoo violence: the multidimensional perspective]. Intervención Psicosocial, $12,32-41$. 


\section{Research of the Factors Responsible for Gender Violence in Home and School Environment}

17. Estévez, E., Murgui, S., Musitu, G. and Moreno, D. (in press). School violence in adolescence: An analysis of mediators of family and classroom environment effects by gender. Journal of Adolescence (accepted in September 2007)

18. Evans, M., Heriot, S. A., and Friedman, A. G. (2002). A behavioural pattern of irritability, hostility and inhibited empathy in children. Clinical Child Psychology and Psychiatry, 7, 211-224.

19. Feagans, L. V., and Bartsch, K. (1993). A framework for examining the role of schooling during early adolescence. In R. M. Lerner (Ed.), Early adolescence (pp. 129-142)

20. French, D. (1988). Heterogeneity of peer-rejected boys: Aggressive and nonaggressive subtypes. Child Development, 59, 976-985.

21. Graham, S., and Juvonen, J. (2002). Ethnicity, peer harassment, and adjustment in middle school: An exploratory study. Journal of Early Adolescence, 22, 173-199.

22. Harrist, A. W., Zaia, A. F., Bates, J. E., Dodge, K. A., and Petit, G. S. (1997). Subtypes of social withdrawal in early childhood: Sociometric status and social-cognitive differences across four years. Child Development, 68, 278-294.

23. Hartup, W. W. (1996). The company they keep: Friendships and their developmental significance. Child Development, 67, 1-13.

24. Henry, C. S., Sager, D. W., and Plunkett, S. W. (1996). Adolescents' perceptions of family system characteristics, parent-adolescent dyadic behaviors, adolescent qualities, and dimensions of adolescent empathy. Family Relations, 45, 283-292.

25. Henry, D., Guerra, N., Huesmann, R., Tolan, P., VanAcker, R., and Eron, L. (2000). Normative influences on aggression in urban elementary school classrooms. American Journal of Community Psychology, 28, 59-81.

26. Hoffman, M. L. (2000). Empathy and moral development: Implications for caring and justice. New York: Cambridge University Press.

27. Lambert, S. F., and Cashwell, C. S. (2003). Preteens talking to parents: perceived communication and school-based aggression. The Family Journal: Counseling and Therapy for Couples and Families, 11, 1-7.

28. Laursen, B. (1995). Conflict and social interaction in adolescent relationships. Journal of Research on Adolescence, 5, 55-70.

29. Meehan, B. T., Hughes, J. N., and Cavell, T. A. (2003). Teacher-student relationships as compensatory resources for aggressive children. Child development, 74, 1145- 1157.

30. Moos, R. H. (1974). The Social Climate Scales: An Overview. Palo Alto, CA: Consulting Psychologists Press.

31. Olweus, D. (1978). Aggression in the schools: Bullies and whipping boys. Washington, DC: Hemisphere.

32. Olweus, D. (1991). Bully/victim problems among school children: Basic facts ad effects of a school based intervention program. In I. Rubin and D. Pepler (Eds.), The development and treatment of childhood aggression (pp. 411-447).

33. Olweus, D. (1993). Bullying at school: What we know and what we can do. Oxford: Blackwell.

34. Olweus, D. (1997). Bully/victim problems in schools: Knowledge base and an effective intervention programme. Irish Journal of Psychology, $18,170-190$.

35. Olweus, D. (2001a). Olweus, core program against bullying and antisocial behavior: A teacher handbook. Bergen: Research Centre for Health Promotion.

36. Olweus, D. (2005). Bullying at school: data and intervention. IX International Meeting about Biology and Sociology of Violence: Violence and School. Valencia (Spain).

37. Paley, B., Conger, R. D., and Harold, G. T. (2000). Parents' affect, adolescent cognitive representations, and adolescent social development. Journal of Marriage and the Family, 62, 761-776. Violence and Victimization at School in Adolescence 35

38. Parkhurst, J. T., and Asher, S. R. (1992). Peer rejection in middle school: Subgroup differences in behaviour, loneliness and interpersonal concerns. Developmental Psychology, 28, 231-241.

39. Peterson, R. L., and Skiba, R. (2000). Creating school climates that prevent school violence. Preventing School Failure, 44, 122-129.

40. Reddy, R., Rhodes, J. E., and Mulhall, P (2003). The influence of teacher support on student adjustment in the middle school years: a latent growth curve study. Development and Psychopathology, 15, 119-138.

41. Rubin, K. H., Bukowski, W., and Parker, J.G. (1998). Peer interactions, relationships, and groups. In W. Damon and N. Eisenberg (Eds.), Handbook of child psychology: Vol. 3.Social, emotional, and personality development (pp. 553-617). New York: Wiley.

42. Thornberry, T. P. (1996). Empirical support for interactional theory: A review of the literature. In J. D. Hawkins (Ed.) Delinquency and crime:
Current theories (pp. 198-235). New York: Cambridge University Press.

43. Trickett, E. J., Leone, P. E., Fink, C. M., and Braaten, S.L. (1993). The perceived environment of special education classrooms for adolescents: A revision of the classroom environment scale. Exceptional children, 59, 441-420.

44. Verschueren, K., and Marcoen, A. (2002). Perceptions of self and relationship with parents in aggressive and nonaggressive rejected children. Journal of School Psychology, 40, 501- 522.

45. www.e4conference.org/wp-content/uploads/2010/04/14en.pdf

46. www.unicef.org/violencestudy/.../Study\%20on\%20Violence_Child-fr ien..

47. http://library.unesco-iicba.org/English/Girls\%20Education/All\%20Ar ticles/Violence $\% 20$ and $\% 20$ Conflict/A\%20Study $\% 20$ on $\% 20$ Violence $\%$ 20against\%20Girls\%20in\%20Primary\%20Schools.pdf

48. https://plan-international.org/.../philippines-toward-a-child-friendly-e duc...

49. Yoneyama, S., and Rigby, K. (2006). Bully/victim students and classroom climate. Youth Studies Australia, 25, 34-41. 